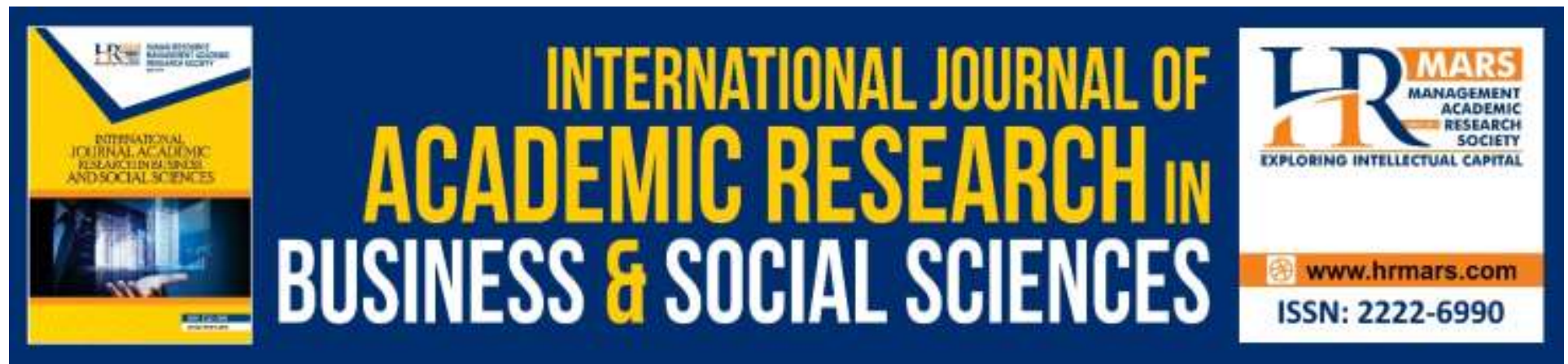

\title{
Analysis of Year Four Pupils' Difficulties in Solving Mathematical Problems Involving Fraction
}

\section{Mohd Azarul Mohd Mokhtar, Ahmad Fauzi Mohd Ayub, Rozita Radhiah Said, Siti Salina Mustakim}

To Link this Article: http://dx.doi.org/10.6007/IJARBSS/v9-i11/6766

DOI: $10.6007 /$ IJARBSS/v9-i11/6766

Received: 10 September 2019, Revised: 25 October 2019, Accepted: 02 November 2019

Published Online: 24 November 2019

In-Text Citation: (Mokhtar et al., 2019)

To Cite this Article: Mokhtar, M. A. M., Ayub, A. F. M., Said, R. R., \& Mustakim, S. S. (2019). Analysis of Year Four Pupils' Difficulties in Solving Mathematical Problems Involving Fraction. International Journal of Academic Research in Business and Social Sciences, 9(11), 1560-1569.

Copyright: (C) 2019 The Author(s)

Published by Human Resource Management Academic Research Society (www.hrmars.com)

This article is published under the Creative Commons Attribution (CC BY 4.0) license. Anyone may reproduce, distribute, translate and create derivative works of this article (for both commercial and non-commercial purposes), subject to full attribution to the original publication and authors. The full terms of this license may be seen at: http://creativecommons.org/licences/by/4.0/legalcode

Vol. 9, No. 11, 2019, Pg. 1560 - 1569

Full Terms \& Conditions of access and use can be found at http://hrmars.com/index.php/pages/detail/publication-ethics 


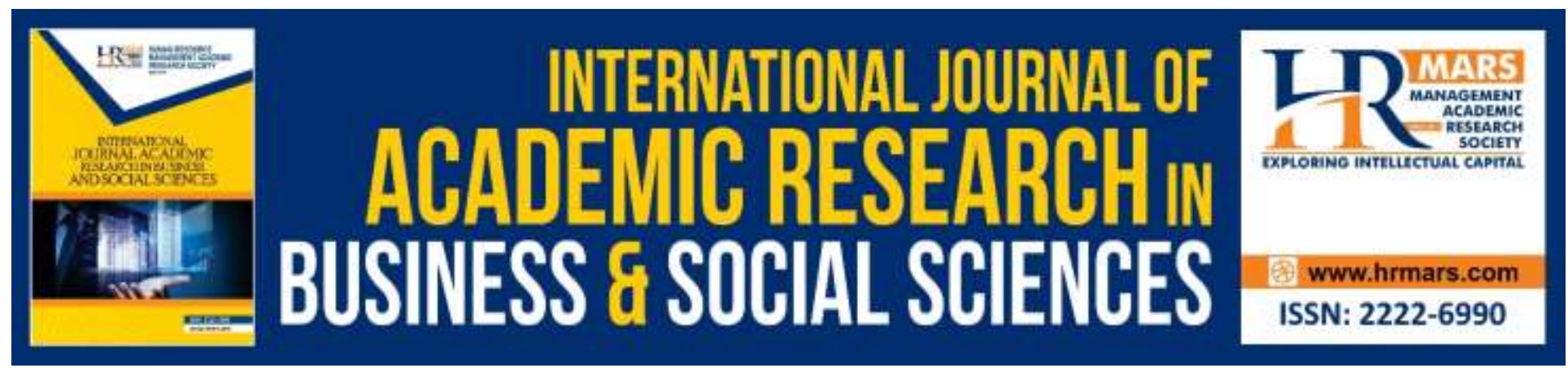

\title{
Analysis of Year Four Pupils' Difficulties in Solving Mathematical Problems Involving Fraction
}

\author{
Mohd Azarul Mohd Mokhtar, Ahmad Fauzi Mohd Ayub, Rozita \\ Radhiah Said, Siti Salina Mustakim \\ Institute for Mathematical Research, University Putra Malaysia, Malaysia
}

\begin{abstract}
Problem-solving is a very important element of Mathematics learning. Unfortunately, the results of the Trends in International Mathematics and Science Study (TIMSS) shows that most pupils are still weak in math problem solving skills. Furthermore, fraction is also a difficult topic for pupils to master. Therefore, this research aims to analyse the types of difficulties faced by Year Four pupils in solving mathematical problems in the fraction topic. The sample was divided into two groups, primary school pupils and math teachers. Data collection was conducted through structured interviews, document analysis and survey testing. Data analysis was conducted using descriptive statistics and content analysis. The results show that there are some difficulties in solving problems in fraction, which are: 1) Pupils have difficulty in understanding the keywords and fail to convert to the correct mathematical sentence, 2) Pupils are weak in mathematics comprehension, 3) Pupils are weak in basic concepts and 4) Pupils do not like to read long-term math questions. Therefore, the findings of this study will encourage teachers to come up with more effective teaching strategies to help pupils to answer mathematical questions better.
\end{abstract}

Keywords: Problem-Solving, Problem Solving Skills, Fraction, Mathematics Comprehension

\section{Introduction}

The current education system in Malaysia is geared towards the Industrial Revolution 4.0. From elementary school to university level, the explosion of the revolution has grown over time. In line with today's technological advances, education needs to evolve accordingly. The age of teachercentred teaching and learning is no longer relevant in today's education. Presently, teachers are considered facilitators and pupils need to be involved in all activities in total. Similarly, in Mathematics education, teachers need to be more proactive in attracting pupils in learning Mathematics subjects. The approach to the teaching methods used should meet the needs of the pupils, and at the same time provide them with an understanding of each topic learned. This is because pupils need to master the basic skills in Mathematics education to ensure that they do not miss out on enrolling at the highest level in university. In addition, the aim of the Primary 
School Curriculum for Mathematics is to build pupils' understanding of the concept of numbers, basic math skills, to understand simple mathematical ideas and to apply mathematical knowledge and skills effectively and responsibly in everyday life (Ministry of Education Malaysia, 2014b). Therefore, teachers need to vary the teaching methods so that pupils are more interested in performing each task and are always excited to learn something new.

Various issues are often discussed in Mathematics education in Malaysia and abroad especially at the school level where pupils cannot answer real-life mathematics questions, pupils do not understand concepts, pupils lack basic facts and many other related problems. This is particularly troubling because these concerns indicate that the teaching and learning of Maths in schools do not achieve its objectives. In 2011, the results of the achievement of Malaysian pupils in the international assessment, the Trends in International Mathematics and Science Study (TIMSS) showed a decline in the level which was below the international average for Mathematics and Science, followed by declines in national rankings as well. More importantly, 35\% and 38\% of Malaysian pupils failed to achieve minimum proficiency levels in Mathematics and Science compared to the year 1999 (Malaysian Education Development Plan 2013-2025). A common problem among pupils in mathematics learning is that they are not interested in reading problem solving questions (Phonapichat, Wongwanich, \& Sujiva, 2014). One of the factors that have been identified is that they do not understand the math problem. Therefore, they prefer to answer without using the math skills they have been taught. This is evidenced in a study by (Phonapichat et al., 2014) who states that effective reading techniques are the determinants of a pupil's maths achievement.

Therefore, pupils who are poor at reading and thinking will have difficulties in answering math problems. Moreover, the level of readiness for pupils to solve problems in mathematics is still a daunting process.

\section{Problem Solving in Mathematics}

Generally, solving problems in mathematics is not something new and should be emphasised by all parties, especially math teachers. Troubleshooting is a complex process and requires a good understanding. It can be seen from various perspectives, namely problem-solving as mathematical thinking, a heuristic and objective one. Pupils' ability to solve problems is a contributing factor to a smooth process of teaching and learning mathematics. (Rohmah \& Sutiarso, 2018) proved in their study that they analysed students' weaknesses using the Newman Error Method. The study was conducted through qualitative methods and involved 147 students. The data was collected through a set of written tests. The study showed that students' weaknesses in solving math problems were due to, the failure to produce all the important information, the inability to convert the information in the form of mathematical sentences, the failure to follow the requirements of the questions and the inability to fully understand the questions.

Additionally, (Raifana, Saad, \& Dollah, 2016) also used the same analysis method in their study. This qualitative study involved 61 Year Five pupils that were divided into three groups: excellent, medium and weak. Data were collected through a set of written test questions and structured interviews. The findings of this study show that gifted pupils are more likely to make 
mistakes at the transformation, process and coding stages. Whereas medium and weak pupils are generally more prone to errors in reading, comprehension and transformation. Furthermore, the study of (Ningrum, Kusmayadi, \& Fitriana, 2019) also used the Newman Error Method to identify the types of students' error in answering math solving questions. This qualitative study involved 20 Grade 7 students at the Surakarta 16 High School, Indonesia. The results of the study found that most students make the mistake in converting information to mathematical sentences due to the failure in understanding the questions. (Duong Huu Tong \& Nguyen Phu Loc, 2017) stated that solving complex mathematical problems is difficult, complex and requires a high degree of intellectual understanding. The qualitative study involved 160 Grade 3 pupils in Vietnam. Researchers had analysed the types of errors by using the Newman Error Method and found out that pupils tend to make mistakes, fail to apply the correct operations, fail to understand the questions and do not count correctly.

In conclusion, solving math problems is a major difficulty for pupils. This is because the problem-solving questions incorporate all the topics learned in school. Therefore, appropriate teaching approaches should be adopted by teachers to ensure that pupils can answer math problems accurately.

\section{Problem Solving in Fraction}

Fraction is one of the topics that are available in the primary school Math syllabus. This topic is very popular though it is not well understood by the pupils due to their failure to understand the concept of fraction. The factor of the procedures in solving fraction questions is still weak among the learners. Furthermore, fraction topic also involves problem solving questions and causes pupils to fail to answer the questions correctly.

This is evidenced in a study by (Nurhani \& Ghani, 2018) who stated that adding fractions for different denominators always confuses the pupils. This qualitative study involved five Year Four pupils with an average level in mathematics subjects. The findings of this study discovered that the mistake that pupils often make when adding denominators in fractions is due to the misconception of the basic concept of fraction. Moreover, the study of (Yusri, Rosnaini, Habibah, \& Shaffee, 2015) also reported on the types of error committed by Year Four pupils while solving problems of addition and subtraction. This qualitative study involved 30 Year Four pupils of a national school in Seri Kembangan, Selangor. In addition, (Fitri \& Prahmana, 2019) also studied the types of mistakes made by pupils when answering problem solving questions. This descriptive study involved 30 Piyungan State junior pupils. The research instrument used was a written test that contains fractional problem-solving questions. The findings show that pupils still make mistakes in solving problems.

Michael J. Bosse, Anass Bayaga, Catherine Fountain, Kathleen Lynch-Davis, Ron Preston and Kwaku Adu-Gyamfi (2018) had studied pupils' understanding of fraction and decimal topics and analyse how pupils build their understanding of mathematical principles and concepts related to fraction and decimal. This study is a case study and discourse analysis that involved pupils in grade 5, 6 and 7. The findings show pupils in various stages of the Mathematics Acquisition Framework (MAF) with some pupils use informal or social language in their mathematical communication while others use formal or academic language. Furthermore, 
pupils' inaccurate ways of mathematical communication are more positively translated through the MAF lens, which interprets pupils' error, misunderstanding, and misunderstanding as a natural component of learning. In addition, a study by (Zakariyya, Beji, \& Itodo, 2018) also conducted an analysis of pupil errors in mathematical sentences questions in fraction topic using the Newman Error method. The study was qualitative and the data was collected through diagnostic test and interview. A total of 105 Year Six pupils selected were from both government and private schools located in Minna Metropolis, Nigeria. The results of this study showed that (16.4\%) errors were from readings, (19.8\%) from comprehension, (18.0\%) from transformations during process skills and coding errors respectively, accounting for $23.9 \%$ and $(21.8 \%)$ respectively.

(Yusof \& Langkan, 2016) used the Newman Error method in their study to analyse the types of pupils errors in answering mathematical questions in the form of sentences for fraction topic. The study is quantitative and supported by qualitative data through observation and pupil interview methods. A total of 37 samples selected consisted of Year Five pupils. The findings of this study show that post-test results do not show a significant improvement. This is because pupils need to understand the concept of fraction well before they can answer mathematical questions with fractional sentences. (Aksoy \& Yazlik, 2017) examine the types of errors and misunderstandings of fractional and operational concepts in fraction topic. The study is qualitative and was conducted in government aid schools as well as private secondary schools in Turkey. This study used 189 samples consisted of high school students with varying degrees of achievement. The study found that students misunderstood and made mistakes in answering fraction questions. It can be seen that students do not use the model on operations with fraction because most errors and misunderstandings are due to the operational calculation with fraction.

As a result, pupils' failure to understand the concept of fraction and the procedure in fraction have caused them to fail to answer the problem-solving questions properly. This indicates that the emphasis on fractional concepts and procedures need to be taken seriously. Hence, teachers need to be more creative in delivering the concept of fraction thus help pupils to answer mathematical questions in the form of fractional sentences accurately.

\section{Methodology}

This study involved two mathematics teachers and 30 primary Year Four pupils in Puchong, Selangor. The pupils involved were mostly low-performing pupils and were identified as having no problems with reading. The topic of problem solving in fraction has been presented to the pupils. The fractional questions were adapted from the Year Four Mathematics textbook (Wan Ngah et al., 2011) and validated by experts in the mathematics field. The analysis of the mistakes made in the pupils' calculations and answers is referred to the study (Prathana Phonapichat et al., 2014) which focuses on three important factors in solving mathematical problems, namely, reading comprehension, computational and mathematics skills.

\section{Results}


The results of the analysis of difficulties in solving problems as described in Table 1 derived from the interviews with the mathematics teachers indicate that, 1) Pupils do not understand the requirements of the questions that lead to the difficulties in mathematics problem solving, 2) Misconception in fraction 3) Pupils do not like to read mathematical questions in the form of sentences, 4) Pupils have difficulty in understanding the keywords that appear in the problem, and therefore cannot interpret them as symbols and 5) Pupils lack of computational and mathematical skills.

Table 1. The result from the mathematics teachers

\begin{tabular}{|c|c|}
\hline Teachers & Results \\
\hline Teacher A & $\begin{array}{l}\text { "Pupils usually have misconception in fraction. } \\
\text { Some of the pupils cannot understand the } \\
\text { problem-solving questions and because of this } \\
\text { reason, they don't like to read it..." }\end{array}$ \\
\hline Teacher B & $\begin{array}{l}\text { "Pupils have difficulty in understanding the } \\
\text { keywords that appear in the problem, and } \\
\text { therefore cannot interpret them as symbols. } \\
\text { Pupils lack of computational and } \\
\text { mathematical skills..." }\end{array}$ \\
\hline
\end{tabular}

The findings as described in Table 2 from the fractionl topical test show that 1) Pupils do not understand the question, 2) Pupils often make mistakes in writing mathematical sentences, 3) Pupils have difficulty interpreting keywords in problems, such as differences intended to avoid problems, but they interpret them as add, 4) Pupils are sometimes careless when they read problems, such as most mistakes "How much do you need to add to 3/7 to get 1?" and they would answer it by only adding two fractions which the answers would be completely different, 5) Weak pupils in math problem solving procedures. They cannot correctly write the procedure in order to solve the problems as described in Table 3.

Table 2. The Result from the Fraction Test 


\section{Problem}

1. The mass of the box $\mathrm{M}$ is $\frac{1}{2} \mathrm{~kg}$. The mass of the $\mathrm{N}$ box is $\frac{3}{4} \mathrm{~kg}$. How much heavier, in fraction, is the $\mathrm{N}$ box than the $\mathrm{M}$ box?

2. Mary has $\frac{3}{5} \mathrm{~kg}$ of beef. She cooked $\frac{3}{10} \mathrm{~kg}$

of meat. How much mass, in $\mathrm{kg}$, of meat is left?

\section{Answer}

$$
\frac{3}{4} k g-\frac{1}{2} k g=\square
$$

Table 3. Examples of topical tests of primary school students on problem solving in fractions

\begin{tabular}{clll}
\hline Student & $\begin{array}{l}\text { What the } \\
\text { problem ask }\end{array}$ & Workings & Difficulties \\
\hline $\mathbf{1}$ (problem 1) & $\begin{array}{l}\text { How much } \\
\text { heavier the N } \\
\text { box? }\end{array}$ & $\frac{1}{2} k g+\frac{3}{4} k g=$ & $\begin{array}{l}\text { wrong } \\
\text { interpretation }\end{array}$ \\
\hline $\mathbf{2}$ (problem 1) & $\begin{array}{l}\text { Which one is } \\
\text { heavier M box } \\
\text { or N box? }\end{array}$ & $\frac{1}{2} k g-\frac{3}{4} k g=\frac{2}{4} k g-\frac{3}{4} k g=\frac{1}{4} k g$ & $\begin{array}{l}\text { Comprehension } \\
\text { error }\end{array}$ \\
\hline $\mathbf{3}$ (problem 1) & $\begin{array}{l}\text { How to add the } \\
\text { fraction? }\end{array}$ & $\frac{1}{2} k g+\frac{3}{4} k g=\frac{4}{6} k g$ & $\begin{array}{l}\text { Misconception } \\
\text { in addition of } \\
\text { fraction }\end{array}$ \\
\hline $\mathbf{4}$ (problem 2) & $\begin{array}{l}\text { How much the } \\
\text { meat is left? }\end{array}$ & $\frac{3}{10} k g-\frac{3}{5} k g=\frac{3}{10} k g-\frac{6}{10} k g=\frac{3}{10} k g$ & $\begin{array}{l}\text { wrong } \\
\text { interpretation }\end{array}$ \\
\hline $\mathbf{5}$ (problem 2) & $\begin{array}{l}\text { How much the } \\
\text { meat is left? }\end{array}$ & $\frac{3}{5} k g+\frac{3}{10} k g=\frac{6}{15} k g$ & $\begin{array}{l}\text { Misconception } \\
\text { in addition of } \\
\text { fraction }\end{array}$
\end{tabular}

The results of document analysis and research related to problem-solving in fraction topic through the interviews with mathematics teacher and pupils' topical test show that 1) pupils do not understand the questions' requirements, 2) pupils are weak in the concept of fraction, 3) pupils do not understand the keywords in the question and fail to write the correct mathematical sentences, 4) pupils do not know how to solve addition and subtraction operations and 5) pupils are weak in the procedure of solving problem-solving problems. This finding is very important for pupils in the mathematical problem-solving process.

\section{Discussions}


Based on the analysis of the research data that has been collected, it was found out that pupils are weak in reading comprehension thus are unable to answer the question correctly. This finding is in line with the study of (Phonapichat \& Wongwanich, 2014) who stated that pupils do not understand what they are reading and do not know how to answer mathematical questions in the form of sentences. Furthermore, the findings of this study are also in line with the study of (Abdullah, Abidin, \& Ali, 2015) and (Santoso, Farid, \& Ulum, 2017) argued that misunderstandings occur when pupils are able to read questions but fail to understand their needs and requirements.

Other findings indicate that pupils do not understand the questions thus fail to find the keywords in the questions. This is in line with the findings of (Hadi, Retnawati, Munadi, Apino, \& Wulandari, 2018) which state that pupils cannot understand what the text means, and cannot begin their thought process to solve the problem. Furthermore, pupils are weak in the basic concept of fraction. This is supported by (Deringöl, 2019) who argues that the reason why pupils make mistakes in math problems is that they lack knowledge of principles, rules, and processes. Their computational skills and understanding are lacking as well. Besides, the lack of mathematical skills and cognitive deficits are also the causes of pupils' inability to solve problems(Tambychik \& Meerah, 2010; Ramli, Talib, Hassan, \& Manaf, 2018; Gitau, Kiragu, Kamau, 2018)

Moreover, the findings of the data analysis show the pupils' weakness in mastering the mathematical problem solving process. This is because problem-solving not only focuses on the final answer but involves more complex factors of understanding and mastery of strategies such as understanding the question, transforming it, performing the identified operations and getting the solution (Raifana et al., 2016). This view is in line with Mayer's $(1985,1987)$ explanation that suggests that the four stages an individual must go through when solving problems are: a) interpreting problems, b) integrating problems, c) planning and finding strategies, and d) implementing solutions.

\section{Conclusions}

This research aims to analyse the difficulty of solving math problems involving fraction among Year Four pupils. The study found that 1) Pupils had difficulty understanding the keywords, hence they could not translate them into mathematical sentences. 2) Pupils are unable to figure out what to expect and what information in the problem that is needed to solve the problem, 3 ) Misconception of fraction and 4) Pupils do not like to read mathematical questions in the form of sentences. This finding is crucial to the problem-solving process and will lead to changes in teaching strategies in assisting pupils in solving mathematics problems.

\section{Corresponding Author}

Associate Prof. Dr. Ahmad Fauzi bin Mohd Ayub

Department of Foundation of Education, Faculty of Educational Studies

University Putra Malaysia, Malaysia

E-mail: afmy@upm.edu.my

\section{References}


Abdullah, A. H., Abidin, N. L. Z., \& Ali, M. (2015). Analysis of students' errors in solving Higher Order Thinking Skills (HOTS) problems for the topic of fraction. Asian Social Science, 11(21), 133.

Abdullah, Y., Mahmud, R., Jalil, H. A., \& David, S. M. (2016). Analysis of mistakes in completing addition and subtration operation of fraction among year four pupils. International Journal of Education and Training (InjET,), 2, 1-9.

Aksoy, N. C., \& Yazlik, D. O. (2017). Student Errors in Fractions and Possible Causes of These Errors. Journal of education and training studies, 5(11), 219-233.

Bossé, M. J., Bayaga, A., Fountain, C., Lynch-Davis, K., Preston, R., \& Adu-Gyamfi, K. (2019). Fraction Learners: Assessing Understanding through Language Acquisition. International Electronic Journal of Elementary Education, 11(2), 113-124.

Deringöl, Y. (2019). Misconceptions of Primary School Students about the Subject of Fractions. International Journal of Evaluation and Research in Education, 8(1), 29-38.

Elementary School Curriculum (KSSR) Curriculum 2010.

Fitri, N. L., \& Prahmana, R. C. I. (2019, March). Misconception in fraction for seventh-grade students. In Journal of Physics: Conference Series (Vol. 1188, No. 1, p. 012031). IOP Publishing.

Ghani, S. N. A., \& Maat, S. M. (2018). Misconception of fraction among middle grade Year Four pupils at primary school. Research on Education and Psychology, 2(1), 111-125.

Gitau, G.G., Kiragu, D.N., Kamau, R. (2018). Effect of Heuristic Factors and Real Estate Investment in Embu County, Kenya, International Journal of Academic Research in Accounting, Finance and Management Sciences 8 (4): 30-38.

Hadi, S., Retnawati, H., Munadi, S., Apino, E., \& Wulandari, N. F. (2018). the difficulties of high school students in solving higher-order thinking skills problems. Problems of Education in the 21st Century, 76(4).

Malaysian Education Development Plan 2013-2025.

Mayer, R. E. (1985). Mathematical ability. Human abilities: An information processing approach, 127-150.

Ngah, W. Y., Lean, L. G., \& Fakir Mohd, R. (2011). Mathematics Year 4 National School. Kuala Lumpur, Malaysia: Language and Library Council.

Ningrum, Y., Kusmayadi, T. A., \& Fitriana, L. (2019). Analysis problem solving about contextual problem of algebraic in junior high school. In Journal of Physics: Conference Series (Vol. 1211, No. 1, p. 012102). IOP Publishing.

Phonapichat, P., Wongwanich, S., \& Sujiva, S. (2014). An analysis of elementary school students' difficulties in mathematical problem solving. Procedia-Social and Behavioral Sciences, 116, 3169-3174.

Ramli, N. F., Talib, O., Hassan, S. A., \& Manaf, U. K. A. (2018). Rasch Analysis and Differential Item Functioning of STEM Teachers' Instructional Preparedness Instrument for Urban and Rural Teachers. International Journal of Academic Research in Progressive Education and Development, 7(4), 211-222. 
Rohmah, M., \& Sutiarso, S. (2018). Analysis problem solving in mathematical using theory Newman. EURASIA Journal of Mathematics, Science and Technology Education, 14(2), 671681.

Santoso, D. A., Farid, A., \& Ulum, B. (2017, June). Error Analysis of Students Working about Word Problem of Linear Program with NEA Procedure. In Journal of Physics: Conference Series (Vol. 855, No. 1, p. 012043). IOP Publishing.

Shamsuddin, S. N. R., Saad, N. S., \& Dollah, M. U. (2016). Analysis of error types by Newman Error method in solving Mathematical life problems among Year 5 students. Journal of Science and Mathematics Education Malaysia (JPSM UPSI), 6 (2), 109-119.

Tambychik, T., \& Meerah, T. S. M. (2010). Students' difficulties in mathematics problem-solving: What do they say? Procedia-Social and Behavioral Sciences, 8, 142-151.

Tong, D. H., \& Loc, N. P. (2017). students'errors in solving mathematical word problems and their ability in identifying errors in wrong solutions. European Journal of Education Studies.

Yusof, J., \& Langkan, J. (2016). Word problems involving fractions: a case of year 5 pupils in Brunei Darussalam.

Zakariyya, A. A., Beji, A. B., \& Itodo, U. (2018). Error analysis of primary six pupils in word problems involving fractions. Sokoto Educational Review, 18(1), 9-9. 